\title{
On Identity, Place, Dignity, and Honor: The Madonnas of Echo Park (2010) by Brando Skyhorse
}

\author{
Amaya Ibarrarán-Bigalondo \\ Universidad del País Vasco, UPV/EHU \\ amaia.ibarraran@ehu.eus
}

\begin{abstract}
Brando Skyhorse's first novel, The Madonnas of Echo Park, set in Echo Park, Los Angeles, portrays the lives, thoughts and feelings of eight different and diverse characters. All of them expose their direct link to the space they inhabit: the barrio. Parting from the premise that the link between space and identity is inextricable, and the fact that the general living conditions and access to different resources is scarce in many U.S. Latino quarters, the aim of this essay is to observe whether the way the characters experience this space affects their personal identity and relation to dignity and honor. Particularly, the way barrio life affects and shapes the personality of male characters. For this purpose, we will employ Alfredo Mirandé's conceptualization of Chicano masculinity, characterized by a strong sense of honor, dignity and pride, among other things. We thus will observe whether a tough environment produces tough men.
\end{abstract}

Keywords: Chicano literature, space, barrio, identity, masculinity

"For a colonized people the most essential value, because the most concrete, is first and foremost the land: the land which will bring them bread and, above all, dignity."

Frantz Fanon, The Wretched of the Earth

The barrio is "a part of a large U.S. city, especially a crowded inner-city area, inhabited chiefly by a Spanish-speaking population" ("Barrio"). This unambiguous definition 
characterizes the social configuration of the barrio by its presumed linguistic homogeneity, depicting it primarily as a place whose inhabitants speak Spanish. Moreover, the description of the barrio as a "crowded inner-city area" hints at its scarce and inadequate basic commodities, as well as its lower class status; it clearly is defined as a non-suburban, low-class milieu.

Echo Park, a mostly Latino neighborhood in Los Angeles, has a population of nearly 44,000 and is one of the densest areas in the city and even in the country. Its average household income and education levels are low compared to the national standard, and half of its residents are foreign born (Mexican and Chinese) ("Echo Park Profile"). Needless to say, this socioethnic configuration marks the lives of its inhabitants and links them with a specific sense of place.

Place and identity, both personal and communal, are inextricably bound. Places (domestic, local, regional, national) shape the identity of the people who dwell in them. However, human beings, as active, socially bound individuals, also construct the specificity of the spaces they inhabit. In this sense, the relationship between place and identity, spaces and people is bidirectional. Diverse psychological studies have confirmed a relationship between space and identity, paying special attention to how space is experienced (Koffka, 1935) and thereby becomes a vital, inner, psychological space (Lewin 1936) — as De Certeau expresses it, space becomes a practiced place (De Certeau, 1988: 117) and thus part of the development of its residents' personal and communal identity.

The Madonnas of Echo Park, the first novel by writer Brando Skyhorse, presents a set of interwoven life stories of different but connected Mexican-Americans/Chicanos who live in Echo Park. The brilliantly constructed novel gives voice to the people of Echo Park and paints a mural of contemporary life in the barrio. The novel depicts a likely unconscious but nevertheless present barrio collective, eclectic identity; the main link among all the protagonists is that they belong to the barrio, the space that inevitably marks their lives and identities. Echo Park becomes the central protagonist of the novel, as its very title suggests, and it is within this specific space that the lives and destinies of the secondary characters are shaped by how they explore and experience the barrio and feel the need to identify with or disavow it.

Within this context, the aim of this essay is to determine whether the ethnic and social characteristics of the barrio as described in the novel and the way that the characters experience this space affect their personal identity and relation to dignity and honor. Specifically, we will look at how barrio life and identity shape the identities of the novel's male protagonists. For this purpose, we will apply Alfredo Mirandé's theorization and conceptualization of Chicano masculinity. Mirandé describes honor, dignity, and pride as the essence of machismo in contrast to the most traditional conception of machismo as related to violence, dominance, and aggressiveness. We thus will determine whether a harsh environment produces harsh men. In Octavio Paz and Samuel Ramos' view which Mirandé calls the compensatory model (1986), historical events have emasculated the Mexican man who, unable to fulfill his dominant role adopts an aggressive, defensive attitude. Therefore, we can conclude that the space 
and attendant socioeconomic conditions in which barrio men live are conducive to the development of this approach to manhood and masculinity.

The history of most barrios in the United States is linked directly to the history of the Mexican-American/Chicano community and the configuration and delineation of Mexican-American and Chicano identities. The bond between this very specific and ethnoculturally marked space and the community which it inhabits has become an essential, defining ingredient of communal and individual Chicano identities. The formation of these spaces dates to the signing of the Treaty of Guadalupe Hidalgo and the annexation of the northern territories of Mexico, as well as of its residents, by the United States. The subsequent marginalization of Mexicanos and urbanization processes in most U.S. cities since the 1920s initiated a twofold sociocultural process that entailed, on one hand, the barrioization or spatial discrimination/segregation (Villa, 2000: 4) of the members of the community and, on the other hand, the formation of a communal identity through the creation of "defensive mechanisms to secure and preserve the integrity of their cultural place-identity within and against the often hostile space regulation of dominant urbanism" (Villa, 2000: 5).

Among these mechanisms, art in general and literature in particular have constructed, produced, and reproduced an aesthetic and conceptual identification of the members of the community with the place to which they belong, thus forging the foundations of a communal barrio identity. The literature created by the Movimiento authors and artists provided a public voice for the diverse yet complementary voices of the barrio, creating an image of the community different than the stereotyped, biased ones present in mainstream cultural production and the media. Similarly, the popular voices of the barrio dwellers were inscribed onto its walls through murals and contemporary graffiti, which served as spaces for communal representation/identification and the writing of a collective, shared history. Corridos, popular songs in general, and other forms of artistic expression depicted and expressed the becoming of a people through a process of group identification and subsequent disidentification from the powerful, mainstream Anglo group. For Raquel R. Márquez, Louis Mendoza, and Steve Blanchar, "the relationship between Anglos and Mexicans since the US Mexican War of 1846-1848 and the Anglo conquest of the northern area of Mexico now known as South Texas has served to frame both groups and to re-enforce their respective socio-cultural identities" (2007: 290).

These groups have evolved and transformed in the decades since the Movimiento Chicano, and although the physical and conceptual gap between the mainstream and peripheral spaces in U.S. cities seems smaller, the reality of life in the barrio is still far from ideal. The barrio and its socioethnic and cultural configuration oftentimes become the space where old-barrio dwellers and newcomers converge, and thus, its cultural and identity characteristics are developing into a more complex, multiethnic milieu in which different sensitivities toward la comunidad and community identity are performed. The contemporary feeling of group identification and strength differs significantly from that which emerged during the times of the Movimiento, when there existed an obvious target and a clear need for assertiveness and identity formation. Barrio Logan and its 
communal struggle for the construction of Chicano Park are a clear example of the past feeling of group strength and social cohesion. In this sense, many works by the first Chicano writers and authors reinforced the relevance of the barrio as a space and as an idea essential to the development of group and individual identity. The barrio, its development, and defense thus became the metaphorical source of the voice of a people, as seen in the works of Rudolfo Anaya, Rolando Hinojosa, and Sandra Cisneros, among many others.

Even a brief review of The Madonnas of Echo Park demonstrates that the link between the protagonists of each chapter is their belonging to Echo Park, as well as their sense of place, honor, and dignity. In this context, we get to know Héctor, a man who has grown up in the barrio and reveals his thoughts about immigration, work, unemployment, and ethnicity; Felicia, a woman who travels to the rich part of town (Los Feliz) to work for a wealthy family; Beatriz, who has become the Lady of Lost Angles after an encounter with Our Lady of Guadalupe; Efrén, a bus driver who cultivates a remarkable connection with and knowledge of the barrio and its residents as he drives around it on a daily basis; and Aurora, a girl who tries to escape the barrio only to return. We meet the real Madonnas of Echo Park, a group of mothers and daughters who dress up as Madonna and dance to her song "Borderline" every Friday at the street corner where video for the song was shot. Here, Alma, the youngest Madonna, is killed in a drive-by shooting while dancing with the Madonnas.

For these characters in this space, Mary Pat Brady's statement about Chicana literature and its drive to expose the significance of spatiality in the formation of Chicana subjectivities may well be applied to Skyhorse's text:

If the production of space is a highly social process, then it is a process that has an effect on the formation of subjectivity, identity, sociality, and physicality in myriad ways. Taking the performativity of space seriously also means understanding that categories such as gender, race, and sexuality are not only discursively constructed but spatially enacted and created as well. (...) Chicanas write with a sense of urgency about the power of space, about its (in)clement capacity to direct and contort opportunities, hopes, lives. (...) These writers also explore the spatialization of subjectivities in process, the efforts to fix or to make subjects through their spatialization, as well as how such efforts get deterred. (2002: 8-9)

The spatial setting of Echo Park thus defines and shapes the subjectivities of all these characters, of the Madonnas of Echo Park and others who dwell in the barrio and construct their racial, gender, and social identity in accordance to it. MexicanAmerican/Chicano identity and its formation, conversely, have been inextricably linked to the idea of reclaiming a decent, human recognition as citizens of the United States. The derogatory and discriminatory terms greasers, spics, pochos, and even wetbacks served as marginalizing labels that not only assigned this community to an utterly inferior status in the sociothenic arrangement of the country but also deprived individuals of Mexican-American descent of any hint of humanity, honor, or dignity. The role of Chicano/a authors and artists has been to erase such negative connotations from the mainstream imaginary and to provide the people of the community with a 
voice through with to recover their social esteem and respect. Spatiality and the sense of place/belonging that the barrio, as a tool of communal strength, represents then are essential in this "process of becoming/humanizing," as can be observed in novels such as The Madonnas of Echo Park. The barrio, thus, is the people, and the people live (in) the barrio.

The title of the novel's opening chapter, "Bienvenidos," clearly evokes this conception of the barrio and its residents and acts as a political manifesto addressing loss and accomplishments, place and honor, belonging and being in the margins.

We slipped into this country like thieves, onto the land that once was ours. Those who'd never been here before could at last see the Promised Land in the darkness: those who'd been deported and come back, only a shadow of that promise. (...) We run into this American dream with a determination to shed everything we know and love that weighs us down if we have any hope of survival. This is how we learn to navigate the terrain.

I measure the land not by what I have but by what I have lost, because the more you lose, the more American you can become. In the rolling jade valleys of Elysian Park, my family lost their home in Chavez Ravine to the cheers of gringos rooting for a baseball team they stole from another town. (...)

What I thought I could not lose was my place in this country. How can you lose something that never belonged to you? (Skyhorse, 2010: 1-2)

These opening thoughts brilliantly convey the sense of place and belonging that many of the novel's protagonists, who live in Echo Park, expose and experiment with in their words and actions. This feeling of non-belonging, of having sneaked in in the place they once possessed, is experienced as a loss of dignity which the characters often overcome by inflicting on others in a socially inferior position, reflecting Paz and Ramos's account of the essence of machismo. In this context, many times do the voices in the novel describe immigrants, contemptuously called wetbacks, as people with no rights, illegal aliens who deserve nothing but deportation to their home country which, in many cases, is same as the speaker's.

A set of examples from the novel illustrate this attitude. One of the clearest instances of this feeling of superiority is provided by Efrén Mendoza, a MexicanAmerican bus driver who describes East L.A. as an ethnically segregated quarter and defends his superiority by claiming his Americanness. When describing his total respect for laws and rules, his punctuality, and his pride in his job, he explains that he had to go on strike to fight for his salary and depicts those opposing the strike as follows.

Those socialist Che-worshiping Reconquistadoras complained these strikes hurt poor Mexican workers who cannot afford a car the most. You're a Mexican, they say, trying to bond with me by speaking Spanish. How can you turn against your own kind?, they say. But they aren't my kind. They're not Americans. They're illegals, and the benefits to lawabiding Americans like me outweigh whatever inconveniences these people face breaking our laws. (Skyhorse, 2010: 72) 
Efrén constructs and deploys his all-American identity with a completely defensive attitude and opposes his honor, respectability, and dignity against those whom he considers inferior, or even "scum."

These new wetbacks don't see it that way. They're picky about what jobs they'll do and how much money they'll accept for the "privilege" to come and do half-assed work at your house. A lot of my riders are mojados going to MacArthur Park to buy fake IDs, passports, and birth certificates with forged birth dates. Papers in hand, they assemble in fixed meeting areas around the park-in front of the police, who won't touch them-to be picked out for odd jobs and day labor across the city. These aren't Mexicans who've lived in this country for years, looking to legitimize a life they've worked hard to build here. They aren't even Mexicans who, from what I've learned about the Mendoza name in libraries, became Americans when the border flipped on us, vanishing years of Mexican heritage with a quill stroke, turning rich landowners into migrant settlers in a new and hostile country. No, these are country hicks, mojados who've made no effort to assimilate, learn English, and do the hard work to become a part of American society the way I did. If I had time off from work, I'd be right out there with those Minutemen on the border, bullhorn in hand, screaming at the top of my lungs. These men looking to take our jobs, and their women who pop off babies for free health care, want schooling for their bastards and welfare from my taxesthey're freeloaders who focus unwanted attention on us legitimate Mexicans, who had to learn the rules and suffers the stings of becoming Americans. Get Mexico to take care of fucking Mexicans for a change. (Skyhorse, 2010: 77)

These bitter, hateful words reflect a pattern of self-defensive discrimination among those who consider themselves marked by difference and, thus, subject to discrimination. The idea of belonging to a place which can be stolen by others of a similar condition defies the status quo of the dwellers of Echo Park, and Efrén stands as an example of an uncontrolled hatred to Mexicans arising from his likely unconscious feeling of inferiority within the mainstream North American socioethnic arrangement. He embodies the idea of territoriality, which Robert Gifford defines as "a pattern of behavior and attitudes held by an individual or group that is based on perceived, attempted, or actual control of a definable physical space, object, or idea and may involve habitual occupation, defense, personalization, and marking of it" (1987: 137). In this sense, Efrén's words connect place and territorial property or belonging to social status, and he turns his resentment and hatred against the newly arrived to the extent of depriving them of any dignity and honor, traits which he assumes only he deserves due to his legal status. His idea of achieving the American Dream through personal effort and sacrifice indicates his complete assimilation into the foundational notions of American democracy and the freedom to pursue one's destiny through dedication and work. At the same time, his thoughts reveal a highly derogatory, machista attitude toward women, whom he describes as using motherhood and their babies to attain citizenship with no effort.

Efrén's contempt and ethnic discrimination toward others he considers to be of a different level than he are even harsher than those held by the mainstream community. He expresses such thoughts as the following: 
General conversation is not permitted between me and my passengers; however, if I see a wetback staying on past MacArthur Park, I have been known to ask him -in English-if he knows he's heading into the black part of town. If a wetback doesn't habla ingles, I punch my hand and fist together and point straight ahead. Mojados caught past Washington Boulevard are taking a big chance, whether it's day or night, but they go where the work takes them. When I speak English to them, they look disappointed and offended. Can you imagine that? They've played the fucking habla español card from fucking Jalisco to here-that's how they get here so easy - and when they meet a Mexican who won't play that game with them, they have the nerve to challenge me on my fucking Mexican-ness! (Skyhorse, 2010: 78)

Once again, Efrén's merciless, ruthless words indicate nothing but his assimilation and reproduction of existing institutional policies, such as those in Arizona Senate Bill 1070, which deprive human beings of their individuality and human dignity and degrade them to an unconceivable extent. Spatiality and national belonging also establish (in a more global sense than the territorial boundaries of the barrio) a human hierarchy measured by dignity and honor. Sadly enough, this degradation of those who do not belong to the supposedly superior space/territory is practiced by a person of a similar condition and ethnic background as those whom he profoundly despises.

The barrio, Los Angeles, or the United States thus provides for these individuals dignity, honor, and identity they apparently could never find in Mexico, which again is constructed in their minds as a substandard place, lacking the basic resources necessary for human needs. Another character, Héctor, an illegal worker, expresses this view when he is hired to perform a job involving a death. Héctor's manager says:

"Hec here's going to help 'manage' the problem you created earlier this afternoon," Tenant says.

"Fine with me," Adam says and motions a waiter I don't see for a drink. "As long as he knows how to keep his fucking spic mouth shut. One call to La Migra and he's headed back to Mexico."

I know this, and it terrifies me. It terrifies me because Mexico doesn't exist for me. I have no memory of it. I was a few months old when my mother brought us to Los Angeles from my birth home in Guanajuato. We settled in a Mexican neighborhood called Chavez Ravine but were evicted when the city took back the land to build Dodger Stadium. Mexico is as foreign to me as Mars, Paris, or Florida. I have no heartbreaking story of the journey here; the heartbreaking story is here, in this small couple of square miles of land called Echo Park. Running through the desert, trying to stay ahead of the border patrol or the Minutemen or the coyotes or the rats isn't the story. It isn't the getting here, it's the staying here. (Skyhorse, 2010: 20)

The examples analyzed so far all concern male protagonists who share their thoughts about place identification, personal and communal identity, and their effect on personal dignity and honor. Although the title The Madonnas of Echo Park implies the prominence of female characters, the work has an even balance of male and female 
protagonists. At this point, it would be interesting to observe the effects of place dis/identification on female honor and dignity and compare them to those of their male counterparts in order to reach conclusions. The first woman introduced in the novel, Felicia, provides a good example. Of Mexican descent, Felicia from the beginning describes herself and her identity as directly connected and tied to the barrio and, thus, to the place/space of Chavez Ravine and Echo Park. Her job as an assistant to a wealthy family in Los Feliz (note the semantic game the author plays with the ideas of place, happiness, personal identity, and character names) requires her move daily through public transportation (in Efrén's bus, to be exact) to a wealthier, richer, and thus supposedly happier quarter in the city. However, this travel has not been the first Felicia has endured. The narration of her story starts as follows:

Spring is here and it makes my joints ache. All those jacaranda blossoms on the walk outside to sweep up. Jacaranda trees thrive in Los Angeles, like blondes and Mexicans. There's no getting away from the, not even in my dreams. They've haunted me from childhood, when I believed a jacaranda tree would save me. Can you imagine such a thing, a tree saving a life? A silly girl thought so once.

I'd been sent to my grandmother's home in Chavez Ravine by my mother whose face I didn't remember and whose cruelty Abuelita wouldn't let me forget. The dirt road outside my abuelita's house led to an outdoor Mercado and was covered with an amethyst sea of pulpy jacaranda that felt like old skin and calico under your bare feet. I'd collect sprays of young jacaranda, then run down the road with them petals ranging from my arms.

When the white men came to build a baseball stadium for playing their games, they smoothed the land out like a sheet of paper to bring in their trucks and bulldozers that would destroy our homes. But there was a problem. The land was uncooperative and petty, swallowing contractors' flatbed trucks and, I prayed, the workers themselves into sinkholes and collapsing earths atop surveyors' flags. The jacaranda trees gave them the most trouble. They felled the mightiest bulldozers, which couldn't tear them down without themselves being damaged. I thought that if I grew a jacaranda tree in my room, it would anchor our home to the land and we wouldn't have to leave. (Skyhorse, 2010: 25-26)

The connection to the place that Felicia exhibits differs widely, for example, from that of Efren, who understands it as a means to attain a status superior to others. In Felicia's case, the link seems to be more personal and emotional, and the natural, earthy nature of her discourse clashes directly with the bus driver's more functional, even cartographic one. The vision of a once natural barrio, full of jacaranda trees whose roots are older and stronger than any man-made plan, is evident in Felicia's words as she makes a direct contrast between "our homes" and the white men and their games. The contradiction between the white, male, all-American symbol of baseball and the domesticity and femininity of "our homes" reflects the implications of territoriality and belonging for a woman who was born in, raised in, and identifies with a space which has been shaped and reshaped by and against the priorities and needs of those who live in it. Felicia's words and the figure of an ancestral tree that connects the people to the land and brings a little light of humanity to a "concretized" quarter are reminiscent of Cisneros' The House on Mango Street's chapter "Four Skinny Tress:" "Four who do not 
belong here but are here. (...) [f]our who reach and do not forget to reach. Four whose only reason is to be and be" (1987: 74-75).

Considering on a more personal level the main subjects of this essay, dignity and honor, it is interesting to note that the female protagonists seem more accepting or, let us say, resigned to the need to lose one's dignity in order to survive in such a hostile sociocultural environment which the unstoppable process of gentrification is devouring little by little. The everlasting patriarchal line which has characterized the Chicano/Latino personal and family environment supports the stereotyped (through symbols such as La Virgen de Guadalupe and La Llorona) but also real image of the Chicana woman as an enduring, submissive individual who accepts being relegated to the domestic space and dares not subvert the established order. In this sense, the strong tie between the Chicana space (generally the household) and the development or entrapment of the Chicana identity has long been studied by scholars and academics, who have proven that the coming out of Chicana women entails abandoning the domestic space and breaking into the public world in order to explore, situate, and place their new identity.

In the case of the novel's female protagonists, most have taken that step but frequently at the expense of losing part of their dignity and honor. Felicia's words are illuminating in this regard:

Before Rick found me, I was looking for work on a street corner, $5^{\text {th }}$ and San Pedro, near the Midnight Mission. Back then, my English was terrible and Skid Row was where, if you were a woman, needed work, and didn't speak English, you'd gather in a group for the gabachos to come and hire you. (...)

The women came from anywhere in the south, some as far away as Uruguay, each with her own Spanish dialect. The men had their own corner, across the street from ours. They weren't there to defend us when we were harassed (or sometimes raped) by the bums who swarmed the area but to keep an eye on us while they drank, laughed and wolf-whistled the gazelles, beanstalky white women in suits and sneakers who parked their cars in the cheap garages nearby. (...) We had the dignity to waiting silence, yawning in the flat gray sharpness of dawn under a mist of milky amber streetlight. Standing in a straight line, arms folded across our chests like stop signs, we prepared ourselves for a long day of aching mindless work by sharing a religious, rigorous, devotional quiet.

When men want relief they hire a whore. When women want relief they hire a cleaning lady. And they did it the same way-first they examined our bodies. Could we reach the high shelves with the lead crystal without a stepladder? Were we able to find into a crawl space and fish out their children's toys? Were our culos big enough to cushion accidental fall? They never looked us in the eye because they could see us performing those disgusting chores no decent woman would dream of asking another woman to do. (Skyhorse, 2010: 27-28)

This passage shows clear opinions about female and male dignity and their direct relationship to social status and economic superiority. Felicia describes female dignity as a purchasable item which can be measured in economic exchanges. These terrible 
thoughts also convey a very strong feeling of submission and enduring acceptance of this female condition, which ironically, these women bear with incredible dignity.

Returning to the impact of place and territoriality on the lives of women in Echo Park, we can observe that, although the female characters seem to accept their inferior status and concomitant loss of dignity as they are treated as invisible but necessary people, two characters stand out among the rest, representing a total affront to the established order and their predetermined destiny: Aurora Salazar, a woman who the white, male constructors could barely evict from Chavez Ravine, and the Lady of Lost Angels, a woman who wanders the barrio and claims to have seen the Virgin at a bus stop. The figure of Aurora Salazar, the last person to be evicted from Chávez Ravine, represents a people's struggle for the dignity and honor which inhabiting a place enhances, along with their identification with the natural (in this case urban) environment. The history of Chávez Ravine is that of the gentrification and whitenization of a Latino quarter for the development of an all-American leisure space, a baseball stadium. Skyhorse's novel thus denounces the eviction of a people from the place that constituted not only their physical dwelling space but also their cultural and social natural environment. The inextricable link between notions of space and culture become evident in this forced evacuation of a quarter, which evokes the physical and spiritual dispossession of a people of their natural landscape as happened to the first inhabitants of the country for the sake of Manifest Destiny.

Aurora's attitude and actions manifest the slogan that el barrio es la gente, la gente es el barrio.

My first name comes from the last woman evicted from the ground that would become Dodger Stadium. In an effort to lure the Brooklyn Dodgers to Los Angeles, the city agreed to construct a new stadium on a large tract of land north of Downtown called Chavez Ravine. Mexicans racially steered from buying houses anywhere else in the city lived here for years in the long shadow cast by the City Hall building, unnoticed and unmolested. Chavez Ravine was immune to time. Dirt trails, along with a paved road or two tossed in like bleached bones, connected backyards where goats and stray dogs roamed free amid houses and shacks with crooked walls, wooden outhouses, and pie-tin roofs that baked your arms and legs throughout the year. Men pushed trolleys and wheelbarrows laden with fresh fruit, ice blocks, and jugs of water from house to house as if Chavez Ravine were still part of old Mexico and not "modern"-era Los Angeles.

(...)

It took more than God's hands to move Aurora Salazar. Four pairs of hands, to be exact, carried Aurora by her wrists and ankles out of her house in front of new reporters and photographers, down a flight of stairs, and onto a swatch of cracked desert floor. Four Mexican officers from the Los Angeles Sheriff's Department with badges and guns to restrain an unarmed, barefoot woman, clad in a sleeves white blouse and pants with large appliqué butterflies fluttering up and down her legs, from ever entering her home again. Four men to contain one woman's fury. (Skyhorse, 2010: 151-152)

This long passage reveals, first, the socioeconomic condition of the quarter, which likely reflects the general situation of similar spaces in similar cities, and denounces the 
sense of forgetfulness and neglect that its inhabitants experience. However, the description of Chavez Ravine also conveys the feeling of belonging and an apparent freedom, an illusionary sense soon put to an end by the construction of the stadium. Aurora and her fight, personal and individual, become the symbols of a people's struggle against a system that swallows up those who do not belong/are not allowed to belong and thus become highly political and revolutionary. Aurora's honor and dignity, which she dares defend in front not only of the mainstream authorities but also those who have "sold their souls" to the system (such as the Mexican policemen), take precedence over any economic and political claims, and she becomes the voice of the people. Moreover, Aurora stands out among the rest of the characters in the novel, who fight to find a space within the system and are ready to be swallowed by it. Aurora, a poor, humble woman, instead, emerges as the symbol of a people who incorporate their space into their personal and communal identities and defend their ties to it as a political, spiritual, and cultural issue.

Our Lady of the Lost Angels, who claims to have seen the Virgin Mary at a bus stop and spends her days in that spot trying to convince people of the miracle, symbolizes the spiritual meaning of places for the people who inhabit them, conveying the stories and histories that shape the identity of a community. The lady's static position at the bus stop, as if she were part of the urban landscape, represents the people's belonging to places and their relevance in shaping and giving meaning to those places.

This brief examination of some characters of The Madonnas of Echo Park illustrates the indissoluble link between territoriality and personal and communal identity and its effect on individual esteem and the negotiations of identity, honor, and dignity. The male and female characters experience their territorial and sociocultural belonging to a specific place differently. The males tend to be initially more defensive and aggressive but eventually more willing to assimilate, while the females are more (r)evolutionary, I would say. Paz and Ramos' theory of the negative outcomes of colonization on Mexican males becomes especially interesting in this context. For example, Efrén's notion of the possession of the land and its occupation by illegal aliens reveals nothing but a fear of the usurpation of the honor and dignity that the land, the barrio, provides to its dwellers. The idea of being colonized again is answered fiercely and aggressively, shaping the identity of the novel's male protagonists into a terrible reproduction of the most negative aspects of the stereotypical concept of machismo. The negative, essentially harsh portrayal of barrio life and the few opportunities for upward mobility that it provides shape a masculine identity that is negative and defiant per se.

\section{Acknowledgements}

This essay is part of a project financed by the Spanish Ministry of Economy and Competitiveness (code: FFI2011-23598) and the European Regional Fund (ERDF). It was also completed under the auspices of the research group REWEST funded by the Basque Government (Grupo Consolidado IT608-13) and the University of the Basque Country, UPV/EHU (UFI 11/06). 


\section{References}

"Barrio." Dictionary.com. Dictionary.com, LLC, 2014. Web. May 15 $5^{\text {th }}, 2005$.

Brady, Mary Pat (2002): Extinct Lands, Temporal Geographies: Chicana Literature and the Urgency of Space. Durham, NC: Duke University Press.

Cisneros, Sandra (1987): The House on Mango Street. New York: Vintage Books.

De Certeau, Michel (1998): The Practice of Everyday Life. Berkeley: University of California Press.

"Echo Park Profile." Los Angeles Times. Tribune Company, n.d. Web. May 15"th 2005.

Fanon, Frantz (1963): The Wretched of the Earth. New York: Grove Press.

Gifford, Robert (1987): Environmental Psychology: Principles and Practice. Boston: Allyn and Bacon, Inc.

Koffka, Kurt (1935): Principles of Gestalt Psychology. New York: Harcourt, Brace.

Lewin, Kurt (1936): Principles of Topological and Vector Psychology. New York: McGraw Hill.

Márquez, Raquel R., Mendoza Louis, and Steve Blanchard (2007): "Neighborhood Formation on the West Side of San Antonio, Texas." Latino Studies 5: 288-316.

Mirandé, Alfredo (1986): "Qué Gacho es ser Macho: It's a Drag to be a Macho Man." Aztlan: A Journal of Chicano Studies 17(2): 63-89.

Mirandé, Alfredo (1997): Hombres y Machos. Masculinity and Latino Culture. Riverside: University of California Press.

Paz, Octavio (1950): El Laberinto de la Soledad. México D.F.: Fondo de Cultura Económica,.

Ramos, Samuel (1962): Profile of Man and Culture in Mexico. Austin: University of Texas Press.

Skyhorse, Brando (2010): The Madonnas of Echo Park. New York: Free Press.

Villa, Raul H (2000): Barrio-Logos: Space and Place in Urban Chicano Literature and Culture. Austin: University of Texas Press. 